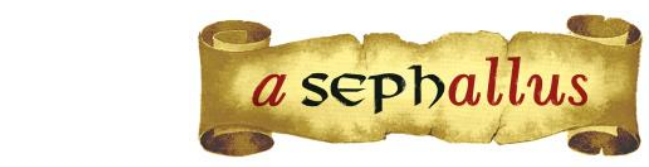

Revista aSEPHallus de Orientação Lacaniana

Núcleo Sephora de Pesquisa sobre o Moderno e o Contemporâneo

ISSN $1809-709$ X

Édipo, Hamlet e os Coûfontaine: reflexões acerca do Grande Outro

Márcia Infante Vieira

Psicóloga pela Pontifícia Universidade Católica do Rio de Janeiro/ PUC-RJ (Rio de Janeiro, Brasil)

Psicanalista membro do Instituto Sephora de Ensino e Pesquisa de Orientação Lacaniana/ ISEPOL

Mestre em Teoria Psicanalítica pela Universidade Federal do Rio de Janeiro/ UFRJ (Rio de Janeiro, Brasil) Doutoranda do Programa de Pós-graduação em Teoria Psicanalítica da Universidade Federal do Rio de Janeiro/ UFRJ (Rio de Janeiro, Brasil)

E-mail: marciainfante@oi.com.br

\title{
Édipo, Hamlet e os Coûfontaine: reflexões acerca do Grande Outro
}

Resumo: Parto da análise de três tragédias - Édipo, Hamlet e a trilogia dos Coûfontaine -, realizada por Lacan nos seminários 5, 6 e 8, pela qual ele mostra os impasses subjetivos existentes entre os interesses do desejo e as exigências da lei fundante da cultura. Abordo o impasse do sujeito com o lugar operatório ocupado pelo Nome-do-Pai, que orienta o discurso de cada um. O que torna evidente a impossibilidade de se prescindir da ideia de que o sujeito é originalmente dependente do Outro, sendo sempre afetado por ele, apesar do rebaixamento do lugar da lei simbólica no laço social. Esta ideia justifica a importância para o psicanalista de saber qual é o Outro com o qual cada sujeito dialoga.

Palavras-chave: Psicanálise; sujeito; Nome-do-Pai; Outro; lei; estrutura

\section{Oedipus, Hamlet et Coûfontaine: réflexions sur le Grand Autre}

Je par de l'analyse de trois tragédies - Oedipe, Hamlet et la trilogie de la Coûfontaine - par Lacan dans les séminaires 5,6 e 8 , oú il montre les impasses subjectives entre les intérêts du desir et les exigences de la loi fondatrice de la culture. Je m'approche de l'impasse du sujet avec la place opérative occupèe par la Nom-duPère, qui guide les discours de chacun. Cela rend évident l'impossibilité de se passer de l'idée que le sujet est à l'origine dependant de l'Autre, toujours affecté par lui, malgré la relegation de la place de la loi symbolique dans le lien social. Cette idée justifie l'importance pour le psychanalyste de savoir quel est l'Autre le quel chaque sujet dialogue.

Mots-clés: Psychanalyse; sujet, Nom-du-Père, Autre, loi, structure

\section{Oedipus, Hamlet, And Coûfontaine: reflexions on the Big Other}

I start from de analysis of three tragedies - Oedipus, Hamlet, and the trilogy of the Coûfontaine - by Lacan in the seminaries 5,6 and 8 , in which he shows the subjective impasses between the interests of desire and the requirements of the fouding law of culture. I approach the impasse of the subject with the operative place occupied by the Name-of-the-Father, who guides the discouse of each one. This makes it evident that it is impossible to dispense with the idea that the subject is originally dependent on the Other, always being affected by it, despite the relegation of the place of the symbolic law in the social bond. This idea justifies the importance to the psychoanalyst of knowing which is the Other with which each subject dialogues.

Key-words: subject, Name of the Father, Other, order, structure 


\title{
Édipo, Hamlet e os Coûfontaine: reflexões acerca do grande Outro
}

\author{
Marcia Infante Vieira
}

A constituição do sujeito da psicanálise depende dos campos da fala e da linguagem, determinada pelo Nome-do-Pai, apesar do declínio da sociedade patriarcal no mundo contemporâneo. Parto da análise de três tragédias - Édipo, Hamlet e a Trilogia dos Coûfontaine, de Paul Claudel - realizada por Lacan em três dos seus seminários: seminário 5, seminário 6 e seminário 8. Para cada uma delas Lacan utilizou-se de um referente e o associou à subjetividade correspondente da época. No caso do sujeito da antiguidade o referente foi Édipo; para o sujeito da modernidade, Hamlet e, por fim, fez uso da trilogia dos Coûfontaine como referência das subjetividades contemporâneas.

Em cada uma delas, ele estudou os impasses subjetivos existentes entre o que é da ordem do desejo e o que é ditado pela lei fundadora da cultura. Esta análise implica, consequentemente, o impasse fundamental do sujeito com o lugar operatório ocupado pelo pai. É através da identificação do significante mestre (Nome-do-Pai) que se torna possível ter acesso ao que orienta o discurso de cada um. Essas leituras tornam evidente a impossibilidade de se prescindir da ideia de que o sujeito, na sua origem, é dependente do Outro, sendo sempre afetado por ele, apesar do afrouxamento do peso da lei simbólica ocorrido na organização do laço social. Essa ideia justifica o quanto é importante para o psicanalista saber quem é o Outro com o qual cada sujeito dialoga.

\section{Seminário 5: complexo de Édipo}

Freud utilizou a tragédia grega, Édipo Rei, escrita por Sófocles em 427 a.c., como um ponto central da teoria e da clínica psicanalítica. A trama edípica veio ao encontro de duas questões sobre as quais ele estava debruçado. A primeira referia-se à sua obstinada pesquisa para encontrar o lugar que o pai ocupava na formação das neuroses, e a segunda, ancorou-se em seu interesse em descobrir os mecanismos dos sonhos.

Foi através de um sonho erótico que Freud teve com sua filha Mathilde - narrado no "Rascunho N", bem como na "Carta 64", endereçada à Fliess (Freud, 1950/1974, p. 350) - que ele descobre a origem da moralidade. Na descrição do sonho, ele anuncia que "Hella era o nome da filha no sonho; num processo de associação, Freud desliza do significante Hella para mitologia da antiga Helaide e lembra o entusiasmo da filha com os heróis helenos" (Moreira, 2004, p. 220). E, termina a carta afirmando: "O sonho, é claro, mostra a realização do meu desejo de encontrar um pai que seja o causador da neurose e, desse modo, pôr fim às dúvidas que ainda persistem em mim sobre esse assunto".

Freud se utiliza da tragédia antiga de Sófocles e interpreta seu sonho a partir da teoria sobre o complexo de Édipo, ou seja, como a expressão de desejos inconscientes. Dessa feita, ele abre um campo para novas significações e avança em sua teorização. Freud descarta a 
possibilidade de que os pais, como até então seus neuróticos the apontavam, na realidade pudessem ser, todos eles, perversos. Identifica um campo de desejos e rivalidades em relação aos pais desde a mais tenra infância e inaugura, com essa descoberta, a dimensão da fantasia como constituinte da estruturação psíquica dos sujeito. Como efeito, o outro ganha um lugar indestrutível nessa estruturação. Nesse sentido, ao tomar Édipo como referente, Freud anuncia que os laços sociais e a subjetividade estariam referidos ao sujeito da antiguidade. Esse sujeito tem, a partir do recalque dos sentimentos incestuosos, sua entrada na civilização. De acordo com Freud, "segundo isto, teríamos um solução: a fantasia sexual se adere quase sempre ao tema dos pais" (Freud, 1950/1974, p. 358).

A relevância do estudo do complexo de Édipo como "complexo nuclear" das neuroses é devido ao fato de que esse enredo possibilitou Freud investigar a sexualidade humana, dando-Ihe um estatuto de estrutura universal. "Será a partir do Édipo que o sujeito irá estruturar e organizar o seu vir-a ser, sobretudo em torno da diferenciação entre os sexos e de seu posicionamento frente à angustia de castração" (Moreira, 2004, p. 220).

Lacan, no Seminário 5, do capítulo VII ao XIII, se dedica a trabalhar o tema do Édipo. Aprofunda o estudo de Freud a respeito do lugar do pai como um operador estruturante na constituição do psiquismo de cada sujeito. Será mais fácil acompanhar as ideias propostas por Lacan ao somarmos ao estudo do complexo de Édipo as ideias desenvolvidas por Freud (1913) em seu artigo "Totem e Tabu". Esse texto permite que as questões levantadas sobre o complexo de Édipo projetem-se num campo cultural, não se restringindo ao campo individual. Nesse artigo Freud, através de um recurso mítico, apresenta o Outro como um pai perverso e devorador. Nesse caso só há um sujeito, o pai totêmico, cabendo aos filhos o lugar de objetos de sua manipulação. Diante desse pai que 'tudo podia', os filhos se reúnem e tramam seu assassinato. Após sua morte, decidiram que ninguém ocuparia seu lugar, uma vez que quem o ocupasse teria, consequentemente, o mesmo destino. Seu lugar de exceção funda a possibilidade dos irmãos, pela via da identificação, configurarem um novo tipo de laço social. Em outras palavras, a partir da introjeção do pai morto, os irmãos inauguram um novo ideal comum. A riqueza desse mito para psicanálise está na força que esse pai morto passa a exercer enquanto lei.

No Seminário 5, alinhado à essas formulações, Lacan acrescenta a relevância da linguagem e da fala. O significante é considerado a peça fundamental na economia do desejo e na formação do significado. "Entre as palavras, é preciso haver uma que funde a fala como ato no sujeito" (Lacan, 1999, p. 151). No entanto, para isso, é necessário que exista algo que confira autoridade à lei. Trata-se de alguma coisa oriunda e relacionada ao Outro. É a isso que Lacan nomeia como significante. "Aqui chamamos de lei aquilo que se articula propriamente no nível do significante, ou seja, o texto da lei" (Lacan, 1999, p. 152).

Nesse momento de sua teorização, Lacan postulou que o Outro é a sede da lei, sendo o significante a base da lei, ou seja, é o Outro no Outro. Tomando a tragédia de Sófocles como 
exemplo, ele afirma que para que a lei possa ser considerada fundada no pai, o pai foi assassinado. E é pelo fato do pai estar morto de saída que seu lugar é de lei. Daí provém o Nomedo-Pai, inaugurando a cadeia significante assentada na sede do código, isto é, no nível do Outro. No entanto, Lacan vai além, postulando um para-além da mensagem. Ele introduz o traço deste que constitui a lei como tal, que seria o sujeito que porta a fala, o responsável por conferir a autoridade. Estabelece o circuito do desejo disparado pela invocação, pelo apelo, enfim, pela demanda, sem os quais torna-se impossível a satisfação do desejo. E é no nível da fala que a mensagem passa a circular na direção do Outro e, também, é do Outro que a resposta provém. Nesse movimento de vaivém, uma falta se inscreve, uma vez que nunca uma demanda poderá ser correspondida por completo. Todo esse processo envolve três participantes: o pai, a mãe e o filho.

Em seguida, Lacan delineia como estruturante a operação da metáfora paterna, que está intrinsecamente ligada à função do pai, ocupando um lugar central na formação do inconsciente. Segundo Freud (1900), o que se revela como conteúdo inconsciente são desejos sexuais infantis em relação à mãe, que até entrarem na consciência encontravam-se recalcados. O que Lacan nomeou como metáfora paterna é a operação descrita por Freud de substituição do desejo materno pela interdição do pai. Tudo o que se passou antes dessa operação se efetuar encontrase no campo pré-edipiano, e, ao se falar em Édipo, inexoravelmente, está introduzida a questão da função do pai: "...o complexo de Édipo tem uma função normativa, não simplesmente na estrutura moral do sujeito, nem em suas relações com a realidade, mas quanto à assunção de seu sexo" (Lacan, 1999, p. 170-171).

Nesse ponto Lacan associa a assunção do sexo ao complexo de castração. O pai, segundo o autor, tem como papel primordial interditar o desejo da mãe. Dessa feita, ele encarna a lei da proibição do incesto. É nessa operação que a castração se inscreve e o pai exerce sua função, ou seja, é nessa operação que se realiza a metáfora paterna. Vale ressaltar que esse processo metafórico se situa no inconsciente e a triangulação pai-mãe-filho é simbólica.

Ao falar em metáfora, ou seja, no processo de substituição realizado entre significantes, Lacan está referindo-se a símbolos. Essa substituição será considerada o ponto central do complexo de Édipo. Nesse ternário simbólico a criança deseja o desejo da mãe, aquilo para o qual a mãe se dirige para além da criança. Para a criança conseguir romper com esse enredo onde se encontra submersa, e desejar outra coisa para além do desejo da mãe, o pai precisa intervir a partir de sua posição significante ou simbólica. Ao intervir assim, ele funda a primazia da posição do falo no plano imaginário. Esse momento nunca é elidido, uma vez que nele o pai se posiciona de forma a atestar que a mãe não tem o falo. A partir desse ponto, que Lacan considera nodal, "coloca-se para o sujeito a questão de aceitar, de registrar, de simbolizar, ele mesmo, de dar valor de significação a essa privação da qual a mãe revela-se objeto" (Lacan, 1999, p. 191).

Todo esse enredo tem sua fundamentação correlacionada à estrutura. No plano imaginário o sujeito encontra-se diante de ser ou não ser o falo. 0 atravessamento dessa fase abre para o 
sujeito a possibilidade de escolher situar-se numa posição ou noutra. Trata-se de um ponto do qual o desejo depende para articular-se. 0 desejo é uma coisa que se articula, pois está inserido em um mundo onde impera a fala. Sendo assim, o desejo de cada um está submetido à lei do desejo do Outro. $O$ que se apresenta para a criança como o primeiro Outro é a mãe, que se encontra articulada à cadeia significante, uma vez que a mãe é um ser falante, mas sua lei, vale ressaltar, não é controlada. Ela precisa de algo que a sustente, que a castre e libere a criança de uma posição de assujeitamento, ou seja, dos seus caprichos. Esse algo chama-se Nome-do-Pai e indica que o que valida a lei não é a relação da mãe com o pai, mas, sim, sua relação com a palavra do pai. "É por intervir como aquele que tem o falo que o pai é internalizado no sujeito como Ideal do eu, e que a partir daí, não nos esqueçamos, o complexo de Édipo declina" (Lacan, 1999, p. 201). Estabelece-se a partir desse processo metafórico, da metáfora paterna, um ideal de promessa.

O sujeito da psicanálise é afetado e constituído pelo Outro desde sua origem. A dinâmica do seu enredo desejante, bem como as significações e destinos que imputará a sua vida de adulto, também são dependentes de qual é o Outro que configura os laços sociais de sua época. Dessa análise podemos identificar que Freud, ao se utilizar da tragédia de Sófocles para postular o complexo de Édipo como uma fase estrutural e universal do desenvolvimento da sexualidade do ser humano, indicou o lugar do Nome-do-Pai na civilização antiga. Esse lugar se articulava com a palavra sustentada por um valor de verdade. Palavra essa que discriminava os sujeitos pelo gênero e pelo lugar ao qual estavam inseridos na configuração familiar. Havia uma clara diferenciação entre as gerações. Portanto, essa ordenação Ihes conferia uma identidade e uma função, ou seja, seriam homens ou mulheres, e consequentemente pai, mãe ou filho. A tradição sustentava a formação desses laços sociais e se transmitia como valores morais e éticos de uma geração à outra. A castração, ou seja, a impossibilidade de ser e fazer tudo, se encontrava no âmago dessa estruturação social e subjetiva dos sujeitos. Esse enredo localizou-se na época onde as famílias obedeciam à um sistema patriarcal, onde o pai de família era o representante de Deus na Terra.

No entanto, o mundo andou no sentido de questionar toda essa rede estreita de laços sociais comandada pelo patriarcado. Não mais representante de Deus, o Nome-do-Pai declina como lugar de único operador simbólico capaz de regular o laço social. A questão que se segue é a de compreender se perder o lugar de único operador decreta a falência do Outro, ou, na verdade, indica uma mudança na qualidade desse Outro, que virá desdobrar novas subjetividades e novas formações de laços sociais.

\section{Seminário 6: Hamlet}

Vou seguir os passos de Lacan que o permitiram localizar o Outro em uma nova posição simbólica a partir da análise da tragédia de Hamlet. Essa tragédia ilustra o tipo de laço social construído sob a base das leis da sociedade moderna. Nesse caso, o referente é o personagem 
Hamlet. Seu pai aparece como um fantasma, como um ideal de homem, condenado, e the revela como e por quem foi morto. Sua posição difere da do pai de Édipo, pois em nenhum momento da peça ele é evocado como rei, ou mesmo como uma figura de autoridade, o que vem a transformar o modo como se organizam as coordenadas do desejo.

Hamlet, diferente de Édipo, sabe como e por quem o pai foi morto. O "não sabido" desliza para o "sabido", trazendo, como efeito, consequências diferentes no que concerne à constituição do desejo. A revelação de ter sido morto por seu irmão, tio de Hamlet, através da administração de veneno pelo ouvido, dá a Lacan a possibilidade de fazer a seguinte análise: "O que é que entra pelo ouvido, senão uma palavra, e qual é, por trás dessa palavra, esse mistério de volúpia?" (Lacan, 2010, p. 350). Jacques-Alan Miller acrescenta: "[...] é precisamente em torno do questionamento do pai, da função paterna que, a meu ver, se organiza a orientação fundamental desse seminário" (Miller, 2013, p. 18). Enquanto a função do pai no complexo de Édipo é normativa e pacificadora, na tragédia de Shakespeare sua ação é patogênica.

A partir da apresentação e análise do pai de Hamlet feita por Lacan no Seminário 6, as balizas teóricas que privilegiavam a primazia da ordem simbólica, foram questionadas pelo autor. No Seminário 5 Lacan exaltou o Nome-do-Pai e, logo em seguida, o questionou. Sua intenção foi refletir a respeito da metáfora paterna, uma vez que, na tragédia de Shakespeare, o pai aparece humanizado, traído e condenado. Mais ainda, na forma de um fantasma, ele pede o filho que o vingue. Esse pai, segundo Lacan, põe abaixo sua formulação de que o Nome-do-Pai é o Outro do Outro. O Outro também é castrado e nesse nível, o sujeito se depararia com a falta de um significante do Outro que Ihe responda sobre a designação de seu ser. O Outro ganha a marca da castração diante da impossibilidade de fornecer uma "metáfora terminal que faria surgir uma significação definitiva" (Miller, 2013, p. 25).

Diante da falta de uma metáfora que responda sobre a existência do ser na questão to be or not to be, abre-se um novo caminho. Do ponto de vista teórico, Lacan responde a esse impasse conceituando o objeto $a$, objeto que fica de fora da operação da metáfora paterna, sendo um resto da organização pré-genital que escapou ao processo de castração. Caberia a cada sujeito criar um enredo próprio que venha dar conta desse resto. Lacan identificou como fantasia essa fórmula pessoal com que cada sujeito se vincula ao objeto $a$. Essa reformulação encontra um lugar para os objetos pré-genitais que o Nome-do-Pai não absorvia na ordenação via significação fálica. A crença pré-existente era a de que o gozo ligado a esses objetos seria absorvido na fase fálica. No entanto, Miller afirma que um exame apurado dos finais de análise, desde Freud, denunciou a insistência desse resto que representa uma infração à castração. Nesse caso, para que o pai funcione é preciso "que ele tenha um desejo enganchado e regulado por uma fantasia cujo objeto seja, ocasionalmente, um gozo estruturalmente perdido" (Miller, 2013, p. 29).

Antes de passarmos para a terceira tragédia analisada por Lacan em seu Seminário 8, vale ressaltar alguns pontos levantados por Lacan relacionados à tragédia de Hamlet. Um deles é o 
valor de operador estrutural que o pai de Hamlet ocupa na peça de Shakespeare, tanto quanto o pai de Édipo, na peça de Sófocles. Ambos aparecem como determinantes na construção do circuito do desejo de seus filhos. Um outro ponto refere-se ao impacto que essa dramaturgia causa no público, que denuncia a existência de uma dimensão desejante estrutural em cada um de nós. Isso leva Lacan a afirmar que "o inconsciente se define como o discurso do Outro" (Lacan, 2014, p. 306). Nessa peça, para Lacan, fica claro que o inconsciente se presentifica tendo como solo o discurso do Outro. Com isso, ainda podemos manter a premissa de que o sujeito é afetado na sua origem pelo significante, pelo Outro.

Nós mesmos provemos o material do qual se constitui nossa relação com o inconsciente: o significante, quer dizer o vocábulo - é o mesmo que ensino, e passo meu tempo dizendo isto -, o provemos com nosso imaginário, quero dizer, com nossa relação com nosso próprio corpo, já que o imaginário é isso. (Lacan, 2014, p. 307)

De um pai morto fundante da lei que regula os laços sociais na antiguidade - Édipo em Sófocles -, passo para um pai fantasma, humanizado, traído e humilhado - um exemplo do pai da modernidade (Hamlet em Shakespeare). No primeiro caso, encontramos o simbólico dando conta de resolver o grande horror da humanidade, ou seja, os desejos incestuosos. Através da operação da metáfora paterna, o desejo da mãe seria interditado pela lei do pai. No entanto, no segundo caso, Lacan identifica um pai insuficiente por estar, também ele, submetido à castração. Como efeito dessa falta, resta o objeto $a$, com o qual o sujeito, em sua condição de castrado, construirá seu enredo singular, ou seja, sua fantasia. No entanto, ambos situam-se na linha de largada da configuração das subjetividades e laços sociais de suas épocas. Passo para a análise do Seminário 8 , no qual Lacan trabalha o lugar do pai na contemporaneidade.

\section{Seminário 8: Trilogia Les Coûfontaines (Paul Claudel)}

A trilogia de Paul Claudel contém três peças: a primeira, "O Refém"; a segunda, "O pão duro"; e a terceira, "O pai humilhado". O referente de Claudel é o pai humilhado, descrito como um ser humano desprezível. Diante desse lugar ocupado pelo pai, ou seja, diante de uma dissolução mais acentuada da sua função paterna, a peça aponta para além de todo o sentido, no extremo da falta. A interrogação "o que é um pai?", que reside na base da psicanálise desde seus primórdios através de Freud, ganha aqui uma relevância decisiva. Nela pode-se identificar que do pai do complexo de Édipo para o pai dos dias de hoje, a questão do pai mudou significativamente. Afinal, na peça, a quem poderemos identificar como a representação do pai humilhado? Seria o Papa que se tornou refém? Poderiam ser os padres que Claudel apresenta ao longo da trilogia? Ou ainda, seguindo a análise de Lacan, seria Toussaint Turelure? Esse é o retrato da tragédia 
contemporânea, revelando os caminhos e os impasses do homem com o desejo e a lei no contexto da contemporaneidade.

O contexto histórico que funciona como pano de fundo onde se desenvolvem as cenas envolve é o seguinte: as consequências da Revolução Francesa e da queda da Monarquia; o início da Revolução Industrial; a ascensão do capitalismo; os conflitos na Europa; a colonização algeriana e a questão dos judeus. Apresentarei a seguir um breve resumo da trilogia.

\section{Primeira peça: "O Refém"}

A peça "O refém" narra a história de Signe de Coûfontaine. A trama gira em torno dessa moça francesa, antes pertencente à nobreza, e que se vê diante de uma encruzilhada, uma vez que perdera todos os seus familiares e seus bens. Diante de tão lastimável perda, ela toma como missão recuperar suas terras. Para isso, foi aconselhada por seu padre confessor a se casar com o Barão de Turelure, homem responsável pelo extermínio de sua família. Ele era filho de uma antiga criada da família de Sygne, e sua trajetória de ascensão se deu pela aliança feita com Napoleão.

Sygne cede devido a uma chantagem: em troca de seu matrimônio, o Papa, que se mantinha clandestinamente escondido por ela após ter fugido da prisão, seria liberto definitivamente. No entanto, essa renúncia não se deu sem deixar sequelas. Sygne adquiriu um sintoma, um tique nervoso, que a fazia balançar a cabeça em sinal de "não". Esse sinal foi introduzido na peça desde o primeiro momento, quando a protagonista fica ciente da morte dos filhos de seu primo e amante, George de Coûfontaine. Esse não aparece simbolizando um questionamento em relação aos valores da fé e de Deus, referências primordiais de sustentação da existência. De forma desesperada, no início da peça, Sygne aparece ainda tentando resgatar esses valores, ao tentar recuperar um crucifixo que fora encontrado sem cabeça, no fundo do forno de uma padaria, e que havia pertencido a seus ancestrais. Esse crucifixo aparece nas três peças da trilogia apontando para o desmonte que vai ocorrendo nos valores religiosos. Na peça "O pão duro", esse objeto chega a ser negociado e barganhado como algo a ser mensurado pela moeda corrente.

A fragilidade da fé aparece inicialmente na figura do confessor de Sygne, que se utiliza da persuasão para conseguir resgatar o Papa. Ele envolve Sygne em uma trama na qual ela é iludida a estar agindo por sua própria vontade, privilegiando o bem maior em detrimento de si. Por acreditar na missão de salvar o representante de todos na Terra, Sygne renúncia e entra no espaço trágico.

Na sequência da peça surgem outras negociações que não são cumpridas por parte do Barão de Turelure. Diante de seu casamento, caberia a ele devolver as chaves da cidade ao Rei Luis XIII. Para mediar essa negociação, ele escolhe George de Coûfontaine, primo e amante renunciado de Sygne. Exige que George Ihe entregue seu sobrenome para que ele possa passá-lo para seu filho recém-nascido do matrimônio com Sygne. George consente, mas não sem lamentar 
que Turelure tenha assumido o lugar que antes era reservado a Deus, já que Turelure tinha assumido para si o poder de nomear o rei. Essa nomeação até então era determinada pela tradição e o rei era considerado o representante de Deus na terra. Com esse ato Tulerule desconsidera a tradição e se atribui a função de ser a lei.

A tragédia se instala no momento da devolução das chaves da cidade. Esse dia também estava marcado pelo batizado da criança rejeitada pela mãe. Ocorre entre esses dois homens, Turelure e George, um atentado em que foi usada uma pistola. Sygne atira-se no caminho da bala endereçada ao esposo e morre. Mesmo baleada e moribunda ela retoma seu não. Claudel apresenta dois finais para peça e, em ambos, Sygne mantém o tique não até o último momento de vida. Nega-se a reconhecer o marido no final em que contracena com ele e, no outro final, no qual contracena com seu confessor, nega a Deus.

No Seminário 8 Lacan se dedica a pesquisar essa trilogia, retomando a experiência trágica com a intenção de analisar o que vem a ser a fantasia. Empenhado em conceituar o fenômeno da transferência, parte da premissa de que a fantasia é o que podemos equiparar a uma resposta singular endereçada ao S( $)$. Do encontro com o Outro há uma falha, já que o sujeito se depara com sua incompletude "diante de um objeto privilegiado, que é degradação imaginária do Outro" (Lacan, 2010, p. 334). Cabe à fantasia tamponar essa hiância através da construção do enredo que visa dar conta do que resta dessa operação. E é justo nesse solo que nasce o desejo. É por essa vertente que Lacan acredita que a tragédia, mais uma vez, Ihe possibilita lidar com os circuitos do desejo.

Para o autor, essa tragédia contemporânea começa fazendo bascular os valores da fé. Isso fica denunciado, a princípio, pela coerção exercida pelo Imperador sobre a pessoa do Papa. Outro valor místico atacado foi o vínculo da nobreza com a terra, uma vez que a família em questão, os Coûfontaine, são desapropriados e perdem seus privilégios como consequência da Revolução. No entanto, Lacan identifica em Sygne, na sua evasão e opressão sofridas, o ponto focal dessa peça. Já o Barão de Tulerule é uma personagem que atravessará e dominará a trilogia como um todo. Ele aparece não só como cínico e desprezível, mas também como um homem muito feio.

Mais do que a renúncia de Sygne, vai interessar a Lacan o padre, confessor dela. Ele exerce o papel de conselheiro, apelando, através do constrangimento religioso e da fé de Sygne, para que ela abdique de seu próprio ser. Nesse caso, ela atinge uma dimensão para além do sacrifício. Essa renúncia radical leva-a ao suicídio, uma vez que ela se encontrava em estado de "perdição absoluta".

Seu tique, o não, ou seja, o seu sintoma, tem valor de mensagem, já que vela e desvela, simultaneamente, o discurso que ele abriga, ou seja, a articulação significante. No momento de sua morte, nos dois finais, ele é retomado, reforçando a dimensão trágica da atitude da personagem. Ela renuncia, também, nesse momento final, à reconciliação com a fé, com Deus, com a paz e, mais ainda, se furta de ver seu filho, fruto indesejado. Nenhum laço de negociação 
com a vida se apresenta, ficando bastante claro que mais nenhum objeto será capaz de iludi-la, fazendo-a desviar desse momento final e radical, no qual o desejo vem a se realizar na sua própria extinção.

\section{Segunda peça: "O pão duro"}

Essa peça evidencia, através do seu cenário, o contexto onde a trama se desenvolverá: "o grande crucifixo está tombado debaixo do retrato do Rei Louis-Philippe, no qual está usando o uniforme da guarda nacional; ao fundo, os livros retirados das prateleiras estão, também eles, tombados pelo chão, em grande desordem" (Maurano, 2012, p. 77).

O tempo passou, mas Turelure continuou o mesmo homem desprezível. Seu filho com Sygne - Louis -, a criança rejeitada, aparece nesse momento com 30 anos e noivo de Lumir. Claudel desnuda o lado obsceno da lei através de um diálogo entre Turelure e Lumir. Essa moça, polonesa, havia guardado sob seus cuidados um montante de dinheiro referente à luta de seu povo polonês. Ao se apaixonar por Louis, e vendo que ele estava em dificuldades, deu-lhe esse dinheiro. Sentindo-se culpada pela traição a seu povo, encaminha-se para Turelure na intenção de resgatar através do pai a dívida do filho. O pretenso sogro negou-se a pagar e, ao ser questionado por ela sobre o seu respeito para com as leis, sua resposta é a de que as leis são feitas por ele.

Nesse momento da peça a arbitrariedade ganha o protagonismo e desfila as suas consequências, tais como: a trapaça, as negociatas, o dinheiro se impondo como valor decisivo, dívidas e usurpações. A terra, que anteriormente tinha um valor sagrado, encontra o caminho da expatriação e o desterro. Duas mulheres surgem representando o protesto e a indignação. Primeiramente, Lumir, que se insurgiu contra a ocupação de seu país pela Rússia. Depois, Sichel, mulher judia, amante de Turelure. Sua revolta era com o fato de a terra prometida ter sido substituída por qualquer valor monetário. Com isso, Sichel declara-se descrente de Deus. Esse aspecto se potencializa diante da afirmação de Louis em um diálogo com Lumir, quando afirma que não existe pátria e, sim, cada um.

A importância dessas duas mulheres na trama cresce na medida em que elas tramam a morte de Turelure. Louis é usado por ambas como instrumento de tal execução. Como filho rejeitado, Louis não desiste e, mesmo no momento de maior confronto, apela por algum reconhecimento paterno. Foi em vão. Somente no duelo com o filho, vendo-se diante da ameaça de morte, é que Turelure apela para os sentimentos religiosos de Louis, suplicando-lhe pela sua crença em Deus. Dessa vez coube ao filho sustentar a recusa. As duas pistolas foram acionadas ao mesmo tempo, mas Turelure morre mesmo é de medo. Esta característica de sua morte denuncia a fraqueza e a vulnerabilidade desse pai.

Nessa peça também não é a morte que encerra a tragédia. Em seu desdobramento Lumir abandona Louis e segue para a Polônia carregando consigo o dinheiro resgatado. Louis recusa-se a acompanha-la, já que havia sido traído por ela. Na tramoia para matar seu pai, o combinado era 
carregar as armas com balas de festim. Conheciam a covardia de Turelure e puderam prever sua morte pelo susto e pelo medo que surgem nele quando ouve qualquer estampido. No entanto, Lumir carregou as duas armas com balas verdadeiras. Diante disso, fica evidente sua intenção de levar o noivo ao cadafalso.

A partir dessa revelação, a peça sofre mudanças de rumo. Sichel passa a ser a herdeira de Turelure, aparecendo, inclusive, sua persuasão sobre Turelure, no sentido de que ele the deixasse sua herança, evitando com isso que Louis pudesse matá-lo. Como Louis não negava o sangue paterno que Ihe corria nas veias, casa-se com Sichel e apropria-se duplamente do que era do pai, ou seja, seus bens e sua mulher.

A peça termina com um final significativo representado por um diálogo entre Louis e o pai de Lumir, um antigo comerciante e comparsa nas trapaças de Turelure. Nesse final, esses homens negociam o valor do crucifixo, o que aponta para a derrisão de Cristo. Louis pediu para o outro homem se livrar desse objeto decaído e sem valor de mercado. Sichel, que estava presente na cena, tenta resgatar o valor do crucifixo uma vez que era uma peça do século XVI. Louis identificao como um objeto danificado e restaurado por sua mãe. Na negociação, Louis chega ao ponto de sugerir que se batesse com uma chave no crucifixo para que sua constituição fizesse com que valesse mais. Sugere vendê-lo por cinco francos o quilo e recebe do comerciante a contraproposta de quatro francos por quilo. Cristo foi arrebatado por esse valor, tendo perdido seu lugar de adoração por ser filho de Deus.

Essa segunda tragédia da Trilogia de Claudel parece situar o ponto de corte, de esgarçamento de qualquer sentido. Sygne se sacrificou em nome do Papa e na intenção de restaurar a legitimidade das terras, mas foi em vão. Algo se instaura para além da fé e, a partir de então, entra-se em uma dimensão de uma grande negociata. Tudo passa a ter um preço. E é a isso que Lacan nomeia como Tragédia do Sentido. Podemos ver no desenrolar da peça um desfile desse esgarçamento dos valores na crença: "[...] em Deus, no amor conjugal e em qualquer coisa que possa tomar o lugar de um ideal a ser atingido" (Maurano, 2012, p. 79). Isso não significa que na contemporaneidade não exista lei. Significa que a lei que vai operar é a lei do capital, a lei do mercado. Uma vez que tudo fica reduzido à mercadoria, a época correspondente passa a ser comandada pela arbitrariedade. Essa arbitrariedade faz vacilar os lugares e papéis que prevaleciam tanto na época antiga como na moderna. A tradição, a terra, a fé em Deus, os valores religiosos e os laços consanguíneos que anteriormente eram inegociáveis, passaram a ter um preço.

Como vimos anteriormente, a lei era fundada na introjeção do pai morto que, desde o artigo de Freud (1913) "Totem e Tabu", dava ao gozo do pai um estatuto de impossibilidade. E era na via desse impossível que o pai morto adquiria seu valor como operador estrutural. Nessa peça, entretanto, parece que esse gozo é reintegrado e o pai não mais se encontra castrado. Sem a castração, a função do pai se compromete, deixando aparecer no horizonte da clínica psicanalítica, segundo Lacan, o "que vemos mais, e cada vez mais, no fundo deste Outro que evocamos em 
nossos pacientes, a mãe" (Lacan, 2010, p. 363). Na medida em que a castração é colocada em questão, subsequentemente a constituição do sujeito do desejo também o é. O falo, significante da falta estrutural, funcionando como portador da função significante, está identificado como a mola do desejo. Em decorrência de sua função de significante, seu estatuto é simbólico. Lacan, tendo como suporte a ideia de que a lei só se instaura sustentada pela morte prévia do pai, nos fala a respeito dessa morte:

Que lugar é esse? Pois bem, é justamente o lugar do ponto morto ocupado pelo pai na medida em que já morto. Quero dizer que, unicamente pelo fato de que o pai é aquele que articula a lei, a voz só pode enfraquecer atrás. Da mesma maneira, ou ele falta como presença, ou, como presença, está presente demais. Este é o ponto onde tudo o que se enuncia torna a passar por zero, entre o sim e o não. (Lacan, 2010, p. 365)

Abrindo o caminho para a terceira tragédia dessa trilogia e tendo em vista as maneiras como cada época lida e aborda a relação do desejo com a lei, Lacan deixa de legado a premissa de que bastam três gerações para que se possa identificar a marca desse desejo. A terceira trilogia tratará exatamente esse ponto de composição entre a marca do significante e a sua relação com o objeto parcial. Antes de entrar no estudo da terceira peça, identifica quais seriam as três marcas inscritas nesses três tempos. No primeiro tempo, a marca significante seria Sygne. No segundo, o objeto rejeitado, indesejado, Louis. E, no terceiro tempo, irá surgir exatamente essa articulação entre a marca do significante e a paixão, como resultante da primazia do objeto parcial.

\section{Terceira peça: "O Pai humilhado"}

A protagonista dessa peça é Pensée de Coûfontaine, filha de Louis e Sichel, e neta de Sygne. Ela nasce nesse contexto de perdição e tem como função compensar o sacrifício da avó, ressituando o desejo. Bela e cega desde o nascimento, Pensée transita na vida orientada pela percepção dos ecos. Suas características principais são a paixão pela justiça e a sedução. Devido ao que ela oferece à visão por sua beleza, a personagem é apresentada por Claudel como objeto de desejo. Representa a falta através da sua cegueira, que vem diferi-la da recusa de sua avó. Do seu lado, a fertilidade, e, do lado da avó, a esterilidade. Mostra-se consciente desse seu poder. Podemos identificar essa certeza já no início da peça em um diálogo com sua mãe, em que ela anuncia o objeto de amor que escolhera. "Não é porque eu sou cega que ele deixará de ver minha parte de luz" (Claudel apud Maurano, 2012, p .82). Seu eleito chama-se Orian de Homodarmes, cujo sobrenome significa homem de armas. Ele é sobrinho do Papa Pio, a quem é totalmente fiel.

O cenário inicial é uma festa de máscaras que se realiza em Roma, onde Louis, pai de Pensée, exerce a função de embaixador. Orian não percebe a cegueira de Pensée e, num jogo 
lúdico na festa, deixa-se ser conduzido por ela para passearem no jardim. Ele tem um irmão chamado Orso e aproveita essa ocasião para revelar à Pensée o interesse do irmão por ela. Ele comete duas imprudências: não percebeu a cegueira de Pensée e nem o interesse dela por ele. Ela não declina das suas intenções e acredita poder remover Orian do caminho que ele havia escolhido para si, que era servir a Deus através de uma carreira eclesiástica. Mesmo resistindo aos interesses da vida carnal, ao longo da peça, Orian é capturado pela sedução de Pensée.

Destacam-se na trama dois diálogos entre Pensée e Orian, cujos conteúdos giram em torno do amor, da felicidade e na crença em Deus. No primeiro diálogo, Pensée questiona a ética de seu pai por ter aderido ao catolicismo, não por fé, mas visando seu enriquecimento pessoal. Declara-se sentir não tendo um pai. Esse ponto serve de alavanca para ela questionar sua fé em Deus, atribuindo-Ihe um caráter humanizado. Orian, temeroso diante dessa insubordinação, protesta defendendo e sustentando a fé no Divino. Pensée não se intimida e continua com sua provocação, passando a interrogá-lo sobre o que seria a felicidade. A resposta que obtém de seu interlocutor é que a felicidade está sempre ao lado do Pai, já que ele porta a verdade absoluta e somente sentimentos nobres. Pensée lança mais uma cartada ao argui-lo sobre o que seria, então, essa alegria não alcançada na dimensão da vida terrena. Orian se embaraça demonstrando pouca maturidade para enfrentar esse diálogo e apenas confirma que é uma alegria de outra vida. É nesse exato momento que Pensée resolve revelar-se cega.

Orian fica absolutamente atormentado após essa conversa e, sob esse efeito, resolve confessar para seu irmão o amor que sentia por Pensée. Essa revelação desdobra-se em confusão, o que veio a exigir um mediador. Recorrem ao Papa Pio em busca de solução para o impasse. Nesse momento, Claudel, através das suas personagens, introduz novamente seu questionamento sobre Deus, avaliando a importância da causa que até então Orian defendeu. Para fazer frente ao amor de Orian, o Papa sustenta a posição de que sem Deus o que resta é a morte nua e o desespero.

Adiante, no segundo diálogo entre os apaixonados, a morte ganha protagonismo. Pensée Ihe diz que não há nada que ele possa ver nos olhos dela, e Orian responde que vê a morte que Ihe espera. Ela se mostra assustada e ele prossegue alegando que, desde o primeiro momento que a conheceu, a morte se anunciara para ele. Foi exatamente isso o que ele amou nela.

O passo seguinte foi dado por Orian. Ele vai ao encontro do Papa lhe comunicar que, devido à beleza de Pensée e à sua voz que soara em seus ouvidos como música, ele tinha acessado dentro de si algo que jamais suspeitara existir. O Papa empenha-se em persuadi-lo a abdicar dessa posição e acaba por convencê-lo. Do saldo dessa conversa, Orian sai com a crença de que não seria capaz de lidar com os riscos do amor e identificou que o que Pensée queria dele era a sua alma. Já que não acreditava ser possuidor de uma, chega à conclusão de que não teria o que dar para ela. Orian se despede de Pensée num encontro sem palavras e segue para a guerra, onde, por fim, encontra a morte. 
O amor entre os dois não morre, uma vez que, desse encontro mudo, ela engravida. Nessa terceira peça da trilogia, esse filho significa que ainda sobra um resto de remetimento ao objeto, diferente da renúncia de sua avó Sygne. Por uma carta que a mãe de Pensée escrevera e enviara para Orian ele vem a saber, pouco antes de morrer, que seria pai. Seu último pedido foi que Pensée se casasse com seu irmão Orso. Pensée o realiza, mas segue amando Orian. Desse amor sobra um resto, esse filho que se mexeu no ventre materno pela primeira vez na ocasião em que Pensée recebera um ramo de flores que estavam plantadas no solo em que Orian se encontrava enterrado. Bastou que ela sentisse o perfume exalado pelas flores para que o filho sinalizasse sua existência. É um fruto fora da lei, mas desejado, o que veio a permitir um enlace menos trágico para essa última peça da trilogia.

Lacan inicia a análise dessa peça questionando a significação do nome da personagem Pensée. Acredita, então, que a personagem encarna o desejo do pensamento que, contém em si, o próprio pensamento do desejo. Para o autor, a escolha desse nome não representa uma simples coincidência, mas sim, a comprovação da incidência do simbólico no corpo. Sua sustentação é de que esse atravessamento do significante na carne é o que constitui o sujeito barrado nas suas duas facetas, isto é, marcando-o e desfigurando-o simultaneamente. A partir desse ponto, nos conduz ao caminho dessa marcação em Pensée, acreditando ser necessário retornarmos para a primeira peça da trilogia, especificamente, para o ponto do sacrifício radical da paixão de sua avó Sygne. Identifica nessa renúncia radical a abertura de uma recusa profunda da operação feita pelo verbo, o que se desdobrará em um abismo colossal. É aí, segundo Lacan, que reside a origem da tragédia, não devido a um fanatismo religioso por parte de Sygne, mas pelo fato de ter renunciado a todas as crenças de sua vida, aos seus propósitos.

Quanto ao caráter religioso, Lacan não acredita que ele por si só geraria a tragédia. 0 autor vai além e denuncia que é essa dimensão da loucura religiosa o que falta ao homem contemporâneo. Através do seu tique da cabeça, Sygne diz não a toda imposição que sofreu e revela, assim, a dimensão do inconsciente do sujeito, do sujeito do recalque, do sujeito do inconsciente. Claudel nos apresenta a representação do Deus morto através da figura do Papa que foi feito de refém. Lacan parte desse ponto e alega que diante da morte de Deus ficamos reféns do Verbo. É neste ponto que se localiza o trágico em Sygne, pois ela é mantida como refém em sua própria negação. Ele nos diz:

O homem se tornou Refém do Verbo porque disse a si, ou também para que dissesse a si, que Deus está morto. Nesse momento abre-se essa hiância onde nada mais pode ser articulado senão o que é somente o próprio começo do não fosse eu, que não poderia ser mais que uma recusa, um não, esse tique, esse esgar, em suma, essa curvatura do corpo, essa psicossomática, que é o termo onde temos que encontrar a marca do significante. (Lacan, 2010, p. 374) 
Coube à Pensée compensar o sacrifício da avó e se tornar, com isso, merecedora de alguma consideração. Através do seu pensamento livre, sua paixão e sua beleza, a personagem almeja a justiça absoluta que venha abalar o mundo. Seu discurso é animado por esse senso revolucionário. "Essa justiça é o avesso de tudo aquilo que, do real, de tudo aquilo que, da vida, é, graças ao Verbo, sentido como ofensa à justiça, sentido como horror da justiça" (Lacan, 2010, p. 375). Sendo assim, ao longo da terceira peça, podemos ver desfilar essa cega que, por sua sensibilidade, enxerga claramente. Ela encarna o objeto parcial e, como tal, atrai para si o desejo, já que o desejo nasce da falta. Essa mulher, nessa posição sublime, substitui a Coisa e indica o caminho possível de se aproximar da Coisa através das suas espécies, através do objeto a. Essa operação só é possível por meio da castração. Aqui, novamente, revela-se a estrutura do desejo. Lacan esquematiza o mecanismo pelo qual a linguagem torna-se desejo através da figura da mulher:

Existe sempre no desejo alguma delícia da morte, mas de uma morte que não podemos nós mesmos nos infligir. Reencontramos aqui os quatro termos que são representados, se posso dizer, em nós - os dois irmãos, a e $a^{\prime}$ - nós, o sujeito na medida em que não compreendemos nada disso - e a figura do Outro encarnada nessa mulher. Entre esses quatro elementos, todas as espécies de variedades são possíveis, da morte infligida, dentre as quais é possível enumerar as formas mais perversas do desejo. (Lacan, 2010, p. 383)

\section{À guisa de conclusão}

Para concluir, vou recapitular este artigo a partir da influência do Outro nas três peças e o efeito de seu desdobramento nas três gerações consecutivas. Na primeira peça, "O Refém", vemos o logro do sentido, onde o desejo se esgarça sem medidas e culmina no aniquilamento radical encarnado na personagem Sygne. Na segunda peça, centro da trilogia, o que se apresenta é o contemporâneo naquilo que ele deixa o sujeito à deriva, desamparado, sem recursos para lidar com a voracidade das exigências da satisfação libidinal. Na terceira peça, temos a confirmação da inexistência da relação sexual pela abordagem da forma de amar que, no entanto, deixa um resto, um fruto fora da lei através do qual o desejo é relançado.

Nesse estudo, Lacan sustenta que a psicanálise trabalha sobre a base de que o pai está morto e que na contemporaneidade encontramos esse 'pai humilhado', sua derrisão potencializada. A intenção de Lacan parece ser a de alertar os analistas acerca do papel que thes cabe no ato analítico, mais especificamente, na transferência. Fica claro que ele deixa a advertência de que é impossível pensar no lugar do analista sem levar em conta a relação da psicanálise com a cultura. 
Essa trilogia indica como as circunstâncias contemporâneas se inscrevem na composição mítica do desejo. Claudel permitiu acompanharmos o modo como as formas de abordagem da lei que cada época delineia incide na composição desejante. E de Sófocles a Claudel isso se explicita. Caberá ao analista, atento, identificar a estrutura da fantasia do analisante, levando em conta esse rico legado deixado por Lacan. Se não é mais o Nome-do-Pai que baliza e configura a relação do sujeito com o seu desejo, configurando também os laços sociais, o que faria essa amarração na contemporaneidade?

A constituição do sujeito continuará sempre dependente do campo da fala e da linguagem, mesmo que os significantes mestres que ordenavam a tradição tenham sofrido um processo de destituição de sua função de autoridade. Contemporaneamente, esse campo não é mais determinado pelo Nome-do-Pai, mas por uma variedade deles, como efeito do declínio da sociedade patriarcal. Houve um afrouxamento da lei simbólica que fez vacilar a autoridade da lei que sustentava o lugar de exceção do pai morto. No entanto, acompanhamos que tanto o pai fantasma de Hamlet como o pai perverso da trilogia de Claudel continuaram produzindo efeitos nos discursos dos sujeitos da sua descendência. Nesse sentido, embora a figura do Outro tenha sofrido modificações em seu modo de comparecimento, não há como prescindirmos da dependência do sujeito em relação ao Outro. Ele continua funcionando como operador estrutural.

\section{Referências Bibliográficas}

Badinter, E. (2005). Rumo equivocado: o feminismo e alguns destinos. Rio de Janeiro: Civilização Brasileira.

Brousse, M.-H. (2014). A psicose ordinária à luz da teoria lacaniana do discurso. In Coelho dos Santos, T.; Santiago, J. \& Martello, A. (Orgs.) Os Corpos Falantes e a Normatividade do Supersocial. Rio de Janeiro: Cia de Freud.

Claudel, P. (1990). L'otage: le pain dur et Le Père humilié. Paris: Gallimard.

Coelho dos Santos, T. (2005). Sinthoma: Corpo e Laço Social. Rio de Janeiro: Editora Sephora/UFRJ.

Coelho dos Santos, T. (2014). Do supereu sujeitado à lei simbólica à normatividade supersocial dos corpos falantes. In Coelho dos Santos, T.; Santiago, J. \& Martello, A. (Orgs.) Os Corpos Falantes e a Normatividade do Supersocial. Rio de Janeiro: Cia de Freud.

Coelho dos Santos, T. (2016). O Outro que não existe: da verdade verídica, verdades mentirosas e desmentidos veementes. Trabalho ministrado pela autora no seminário do grupo Sephora de pesquisa/ UFRJ. (Trabalho Inédito).

Freud, S. (1976). Totem e Tabu. In J. Salomão (Trad.) Edição standard brasileira das obras psicológicas completas de Sigmund Freud (Vol. 13). Rio de Janeiro: Imago (Trabalho original publicado em 1913). 
Freud, S. (1974) Extratos dos documentos dirigidos a Fliess. In J. Salomão (Trad.) Edição standard brasileira das obras psicológicas completas de Sigmund Freud (Vol. 3, pp. 251-385). Rio de Janeiro: Imago (Trabalho original publicado em 1950).

Lacan, J. (1999). O Seminário, livro 5: as formações do inconsciente. Rio de Janeiro: Zahar (Seminário proferido em 1957-1958).

Lacan, J. (2016). O Seminário, livro 6: o desejo e sua interpretação. Rio de Janeiro: Zahar (Seminário proferido em 1958-1959).

Lacan, J. (2010). O Seminário, livro 8: a transferência. Rio de Janeiro. Zahar (Seminário proferido em 1960-1961).

Lacan, J. (1992). O Seminário, livro 17: o avesso da psicanálise. Rio de Janeiro: Zahar (Seminário proferido em 1969-1970).

Lacan, J. (2008). O Seminário, livro 20: mais, ainda. Rio de Janeiro: Zahar (Seminário proferido em 1972-1973).

Maurano, D. (2012). Recuperado de http://www.uva.br/trivium/ediçoes/edição-i-anoiv/artigos/claudel-e-as-implicações-da-derrisão-do-pai.pdf.

Miller, J.-A. (2013, dez). O Outro sem O Outro. In Opção Lacaniana - Revista Brasileira Internacional de Psicanálise, no 6. São Paulo: Eólia.

Miller, J.-A. (2010, nov.). Efeito de retorno à psicose ordinária. Opção Lacaniana online nova série, $1(13)$.

Moreira, J. (2004, mai. a ago.). Édipo em Freud: o movimento de uma teoria. Psicologia em Estudo, $9(2), 219-227$.

Ventura, Z. (2013). 1968 o ano que não terminou. Rio de Janeiro: Editora Objetiva.

Ventura, Z. (2014). 1968 o que fizemos de nós. Rio de Janeiro: Editora Objetiva.

Vieira, M. I. (2016). Par ou ímpar? Uma leitura dos impasses das parcerias amorosas entre homens e mulheres na clínica contemporânea. (Dissertação de Mestrado). Programa de Pós-Graduação em Teoria Psicanalítica da Universidade Federal do Rio de Janeiro, Rio de Janeiro.

Citação/Citation: Vieira, M. I. (nov. 2017 a abr. 2018). Édipo, Hamlet e os Coûfontaine: reflexões acerca do grande Outro. Revista aSEPHallus de Orientação Lacaniana, 13(25), 76-92. Disponível em www.isepol.com/asephallus. doi: 10.17852/1809-709x.2019v12n25p76-92

Editor do artigo: Tania Coelho dos Santos.

Recebido/Received: 13/06/2017 / 06/13/2017.

Aceito/Accepted: 05/09/2017 / 09/05/2017.

Copyright: (c) 2018 Associação Núcleo Sephora de Pesquisa sobre o moderno e o contemporâneo. Este é um artigo de livre acesso, que permite uso irrestrito, distribuição e reprodução em qualquer meio, desde que o autor e a fonte sejam citados/This is an open-access article, which permites unrestricted use, distribution, and reproduction in any medium, provided the author and source are credited. 